\title{
Jurnal
}

\section{DeCISION SUPPORT EVALUATION FOR BUILDING INFORMATION MODELING SOFTWARE SELECTION}

\author{
Ahmad Taufik Nursala*, Mohd Faizal Omara, Mohd Nasrun \\ Mohd Nawib
}

aSchool of Quantitative Science, Universiti Utara Malaysia, Kedah, Malaysia

bSchool of Technology Management \& Logistics, Universiti Utara Malaysia, Kedah, Malaysia
Article history

Received

27 April 2015

Received in revised form

15 June 2015

Accepted

15 July 2015

*Corresponding author taufiknursal@yahoo.com

\section{Graphical abstract}

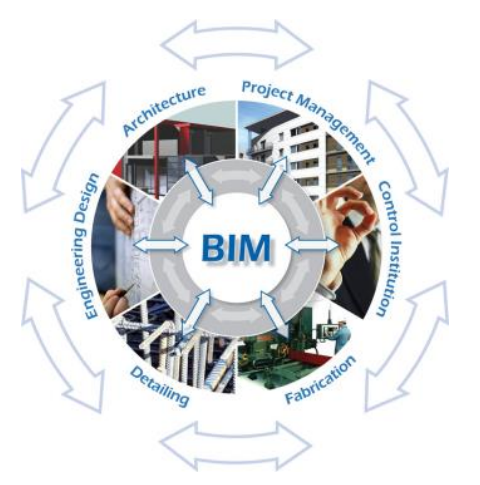

\begin{abstract}
Building Information Modeling (BIM) has shift the construction industry into a new approach in development of project. The effectiveness of BIM towards increasing productivity and quality of project has been reported not only in literature yet project report. Thus, there are numerous of BIM software available with different features and function. This trend has created decision problem among the companies to select the best software that fulfill company need and project needs. Hence, a web-based Decision Support System (DSS) application namely topsis4BIM has been developed. This paper presented the evaluation the proposed DSS though using the latest technology such as web 2.0 and cloud technology.
\end{abstract}

Keywords: Building Information Modeling (BIM), decision support system, usability

\begin{abstract}
Abstrak
Permodelan Maklumat Pembinaan (BIM) telah merubah industri pembinaan ke pada satu pendekatan baru di dalam pembangunan projek. Keberkesanan BIM di dalam meningkatkan productiviti dna kualiti projek telah dinyatakan tidak sahaja di dalam kesusateraan tetapi juga di dalam laporan projek. Oleh itu, terdapat banyak perisian BIM yang telah dibangunkan di pasaran yang mempunyai ciri-ciri dan fungsi yang berlainan. Keadaan ini telah menyebabkan masalah keputusan di kalangan syarikat-syarikat untuk memilih perisian terbaik yang memenuhi keperluan syarikat dan projek. Maka, Sistem Sokongan Pemutusan (DSS) iaitu topsis4BIM telah dibangunkan. Manuskrip ini memaparkan penilaian yang telah dibuat ke atas DSS termaju yang telah dicadangkan dengan menggunakan web 2.0 dan teknologi awan.

Kata kunci: Permodelan Maklumat Pembangunan (BIM), sistem sokongan pemutusan, kebolehgunaan
\end{abstract}

\subsection{INTRODUCTION}

Nowadays, decision making in BIM software selection is becoming more apparent. Literature has revealed the importance of appropriate selection of BIM software towards company and project. However, there is limited study attempts to develop a decision tools in BIM software selection. At present in real world, there is no decision model or decision support tool available for BIM software selection. Thus, this research has developed a web based DSS namely topsis4BIM in order to deal with BIM software 
selection problem. This paper has been divided into four section, the first is more on literature review, second is on architecture of topsis4BIM, third section is on validation process of topsis4BIM, and final section is more on conclusion and discussion of research.

\subsection{LITERATURE}

\subsection{Building Information Modeling}

Due to the increasing of project complexity particularly in design phase has force the construction company to adopt Building Information System (BIM). Nowadays, BIM has been considered as a solution in order to increase productivity and quality of project simultaneously reducing cost and time of project [1]-[4]. The advantages and effectiveness of BIM toward project has been widely discussed in literature. Most of the literature has reported that the function and features of BIM mostly impact the planning and design phases [5]-[7]. The ability of BIM has allows architect to extend the design process thorough 3D visualization and also enable them to build precisely "virtual model" building that represent project outcomes in design phase. With development of 3D model of project outcome, BIM also enable the architect to performed significant building analysis such as clash detection, lighting and power analysis within the model. This is significantly beneficial toward Construction Company in order to reduce the design error in future and automatically avoid construction problems such as delay and increasing cost [8], [9]. However, the advantages and features of BIM are not only limited to design phase, BIM can be utilized through the whole phase in Project Life Cycle (PLC) [1], [5].

Literature revealed that most of the company tends to select BIM software based on recommendation other company, vendor section or select the most popular software available in market [3], [10]. With the complexity of the problem and absent of proper decision analysis, the selection of BIM software became more apparent. Till date, there is limited study attempt to develop a decision support tools such as web Decision Support System (DSS) in BIM software selection problem. Thus, this study aim to develop a web based decision support system for BIM software selection. Furthermore, the evolution of Information Technology (IT) has enhance and simplified the development of web based DSS.

\subsection{Evolution of web DSS}

The development of mathematical decision model for solving real problem is quiet ineffective and less impact without tools to deliver it for user used. Thus, there is a need to develop a DSS in order to increase the utility of decision techniques. DSS has gained much attention among the researcher in construction field. This is due to the effectiveness of DSS in assist decision makers in order to deal with structured, semi structured and unstructured problems. As, a result, numerous of DSS has been developed in order to cater construction problem such as DSS for demolition waste management [11], Application of data warehouse DSS [12], DSS for environmental assessment [13], and Entropic risk analysis DSS [14] and DSS for building construction scheduling [15]. However, due to the rapid development of web technology, the emerging of new concept of web technology called Web 2.0 in 2004 has simplify the development of web based DSS. Theoretically, the development of Web based DSS through web 2.0 is more simple, without any heavy programming language yet effective. The first explanation of Web 2.0 has been explained by Tim O'Reilly (2005). Table 1 below contained the differences between Web 1.0 and 2.0 generation.

Table 1 General comparison between Web 1.0 and Web 2.0 [16]

\begin{tabular}{|c|c|c|}
\hline Criteria & Web 1.0 & Web 2.0 \\
\hline Mode of usage & Read & $\begin{array}{l}\text { Write and } \\
\text { Contribute }\end{array}$ \\
\hline $\begin{array}{c}\text { Unit of content } \\
\text { State }\end{array}$ & $\begin{array}{l}\text { Page } \\
\text { Static }\end{array}$ & $\begin{array}{l}\text { Record } \\
\text { Dynamic }\end{array}$ \\
\hline $\begin{array}{l}\text { How to content } \\
\text { Is viewed }\end{array}$ & $\begin{array}{l}\text { Web } \\
\text { browser }\end{array}$ & $\begin{array}{l}\text { Browser, RSS } \\
\text { readers, } \\
\text { Mobile } \\
\text { device, etc. }\end{array}$ \\
\hline $\begin{array}{c}\text { Creation of } \\
\text { Content }\end{array}$ & $\begin{array}{l}\text { By website } \\
\text { authors }\end{array}$ & By everyone \\
\hline Domain & $\begin{array}{c}\text { Web } \\
\text { designer } \\
\text { and geeks }\end{array}$ & $\begin{array}{c}\text { A new culture of } \\
\text { public } \\
\text { research }\end{array}$ \\
\hline
\end{tabular}

Table 1 illustrates the differences between Web 1.0 and Web 2.0 generation in several criteria. From here, obviously shown the platform of Web 2.0 is extending the features of previous Web generation lead to more simple methodology for the development of web DSS. Thus, in this study web 2.0 has been used for the development of web based DSS for BIM software selection.

\subsection{Evaluation and validation of DSS}

According to Khazanchi (1991), the validation of DSS should focused on DSS design, decision methodology and decision result. In parallel with his study, Borenstein (1998) also highly addressed the validation of DSS should be focused in two main components of DSS such as Subsystem Validation and Face Validation. The main idea behind sub system validation process is to ensure the quality of component in DSS. Meanwhile, Face validation is to achieve consistency between designer view and user view in a timely and cost effective way [17]. Validation of DSS is not only significant toward the decision quality, yet also highly considered user 
satisfaction and acceptance [18], [19]. DSS validation approach can be divided into three categories which were quantitative, qualitative approach and integration of both of this approaches [20].

Furthermore, a combination of quantitative and qualitative approach is more effective during development of a prototype [21]. As mentioned by Nielson (2000), through qualitative validation such as heuristic evaluation is at best to be evaluated by 3 to 5 evaluators. This is due the repetition of same behavior at the first 3 to 5 users (Nielson, 2000). One of the qualitative approaches is validation of DSS through case study evaluation [20]. As mentioned by Taroun (2012) DSS validation through case study require two steps which are comparing result between proposed DSS with current practice method and external validation for purposed of evaluating the DSS design and methodology rather than its result. From DSS validation literature, several of studies has been utilized case study as medium for DSS validation [17], [20], [22], [23], [24].

\subsection{ARCHITECTURE OF TOPSIS4BIM}

Due to the promising advantages of Web 2.0 technology in enhancing and simplified the DSS development, topsis4BIM was developed through this contemporary web technology. Figure 2 showed the architecture of topsis4BIM that involved the main component which Model Management, Database and User Interface. One of the web 2.0 platforms has been utilized as a domain and user interface for this web based.

The development of DSS through this platform provide numerous of advantages such as easy to developed, light programming language, interactive user interface and remote. As a sub-system in this DSS, a decision model fuzzy TOPSIS has been developed through one of the product from Google product which is Google spread sheet. From literature revealed the domination of Microsoft Excel as DSS generator in past. This due to the ability of MS Excel that capable handling data, graphic capability, and enable user to performed "what is analysis" and etc. However, in order to increase the usability and utility of topsis4BIM DSS, Google Spread sheet offered more advantages rather than MS Excel which is more to standalone application.

The topsis4BIM also provided database function. In order to enhance the decision process for decision makers in BIM software selection, the utilization another product of Google Drive which Google Doc. The Google Doc has been utilized to keep information of BIM software (such as features, function and system requirement). Thus, activity such as document analysis has been done by filtering and categorizing of BIM software information in hierarchical database model thorough Vendor website, software template and literature. Figure 1 illustrates its architecture.

\subsection{EVALUATION of topsis4BIM}

In order to measure the usability and utility of the topsis4BIM toward solving BIM software selection, system evaluation and validation process has been conducted. A real case study which is UTHM multipurpose hall has been conducted. There are three evaluators namely as Decision Makers (DM) involved in the process, Table 2 shown the brief profile of evaluators.

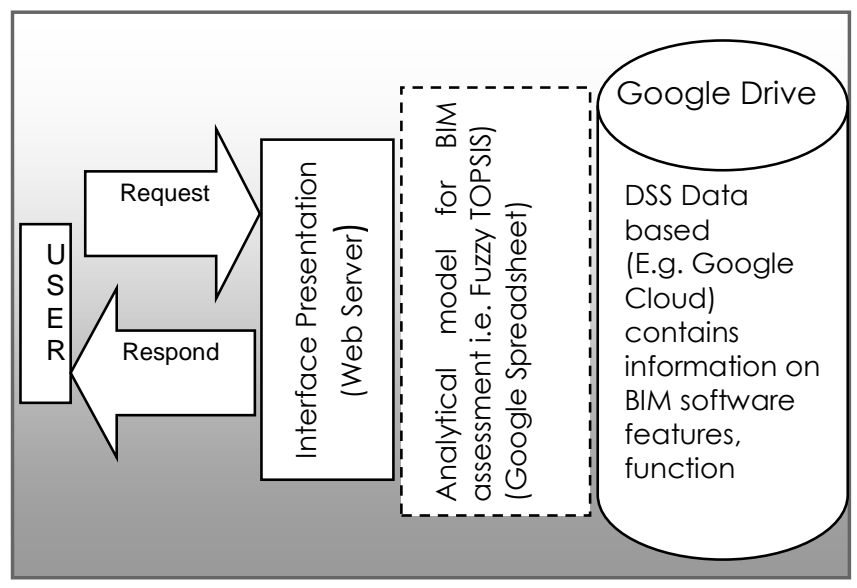

Figure 1 The Arhitecture of topsis4BIM

Table 2 Decision makers profile

\begin{tabular}{lccc}
\hline $\begin{array}{l}\text { Decision } \\
\text { Makers }\end{array}$ & Position & $\begin{array}{c}\text { Background } \\
\text { Work } \\
\text { experience } \\
\text { (Years) }\end{array}$ & $\begin{array}{c}\text { Number of } \\
\text { involvement in } \\
\text { BIM project }\end{array}$ \\
\hline DM 1 & $\begin{array}{c}\text { Consultant } \\
\text { BIM }\end{array}$ & 12 & 8 \\
DM 2 & $\begin{array}{c}\text { Coordinator } \\
\text { Architect }\end{array}$ & 16 & 12 \\
DM 3 & 25 & 5 \\
\hline
\end{tabular}

The purpose of validation process is to assess the level of satisfaction and preference of decision maker toward this web based DSS. Evaluators were asked to use decision model thorough Google spread sheet and with web based topsis4Bim through face validation.

\subsection{Quantitative Result}

A set of usability questionnaire were distributed among the evaluators after the sub-system validation. The level of satisfaction of three decision makers toward decision model was measured through four level of satisfaction which was Very Good (VG), Good (G), Fair (F) and Poor (P). Four criteria were adopted from literature for this purposed (Perceive ease of used, perceived usefulness, preference and willingness). Considering 
that the evaluators are not familiar in decision model evaluation field, 12 sub questions were probed to give them some idea of comments regarding of decision model such as;

1. Perceive ease of use:

- $\quad 1.1$ : easy to use

- $\quad$ 1.2: The process is understandable

- $\quad$ 1.3: It is easy to learn

2. Perceived usefulness

- 2.1: This model helps me control the whole decision process

- 2.2: It makes the decision process easier

- 2.3: It is useful to me in making a decision

3. Preferences

- 3.1: I like to make a decision with this model

- 3.2: I like to analyse information with this model

- $\quad$ 3.3: I like to judge in this way
4. Willingness

- 4.1: I accept the procedure of this decision model for future decisions

- 4.2: I will apply this model for hard decisions in the future

- 4.3: It is worthwhile to use this model in the future

Table 3 and Figure 2 shown clearly how the validation method has improved satisfaction of decision making process among the evaluators between Google spread-sheet and web based. In the post design few of sub questions criteria show significant improvement in term of easy to use decision process easier, useful and worthwhile. It shown that decision makers are prefer using web based topsis4BIM instead of decision model in Google spread sheet itself.

Table 2 Result of face validation

\begin{tabular}{|c|c|c|c|c|c|c|c|c|c|}
\hline \multirow{2}{*}{ Validation criteria } & \multirow{2}{*}{ Sub questions } & \multicolumn{4}{|c|}{ Iteration 1 ( Pre Design) } & \multicolumn{4}{|c|}{ Iteration 2 (Post Design) } \\
\hline & & VG & G & $\mathrm{F}$ & $\mathrm{P}$ & VG & G & $\mathrm{F}$ & $P$ \\
\hline \multirow{3}{*}{$\mathrm{Cl}$} & $\begin{array}{c}\text { Easy to } \\
\text { Used }\end{array}$ & 0 & 100 & 0 & 0 & 0 & 100 & 0 & 0 \\
\hline & Understandable & 0 & 33.4 & 66.666 & 0 & 0 & 100 & 0 & 0 \\
\hline & $\begin{array}{c}\text { Easy to } \\
\text { Learn }\end{array}$ & 0 & 100 & 0 & 0 & 0 & 100 & 0 & 0 \\
\hline \multirow{3}{*}{ C2 } & $\begin{array}{l}\text { Decision } \\
\text { Control }\end{array}$ & 0 & 66.6 & 33.4 & 0 & 0 & 66.6 & 33.4 & 0 \\
\hline & $\begin{array}{c}\text { Decision } \\
\text { process easier }\end{array}$ & 0 & 66.66 & 33.4 & 0 & 0 & 100 & 0 & 0 \\
\hline & Useful & 0 & 66.66 & 33.4 & 0 & 0 & 100 & 0 & 0 \\
\hline \multirow{3}{*}{ C3 } & $\begin{array}{l}\text { Like to make } \\
\text { decision }\end{array}$ & 0 & 66.66 & 33.4 & 0 & 0 & 66.66 & 33.4 & 0 \\
\hline & Like to analyse & 0 & 66.66 & 33.4 & 0 & 0 & 66.66 & 33.4 & 0 \\
\hline & Like to judge & 0 & 66.66 & 33.4 & 0 & 66.6 & 33.4 & 0 & 0 \\
\hline \multirow{3}{*}{ C4 } & $\begin{array}{l}\text { Accept the } \\
\text { procedure }\end{array}$ & 0 & 66.66 & 33.4 & 0 & 0 & 66.66 & 33.4 & 0 \\
\hline & Will apply & 0 & 33.4 & 66.66 & 0 & 0 & 33.4 & 66.66 & 0 \\
\hline & Worthwhile & 0 & 33.4 & 66.6 & 0 & 0 & 100 & 0 & 0 \\
\hline
\end{tabular}




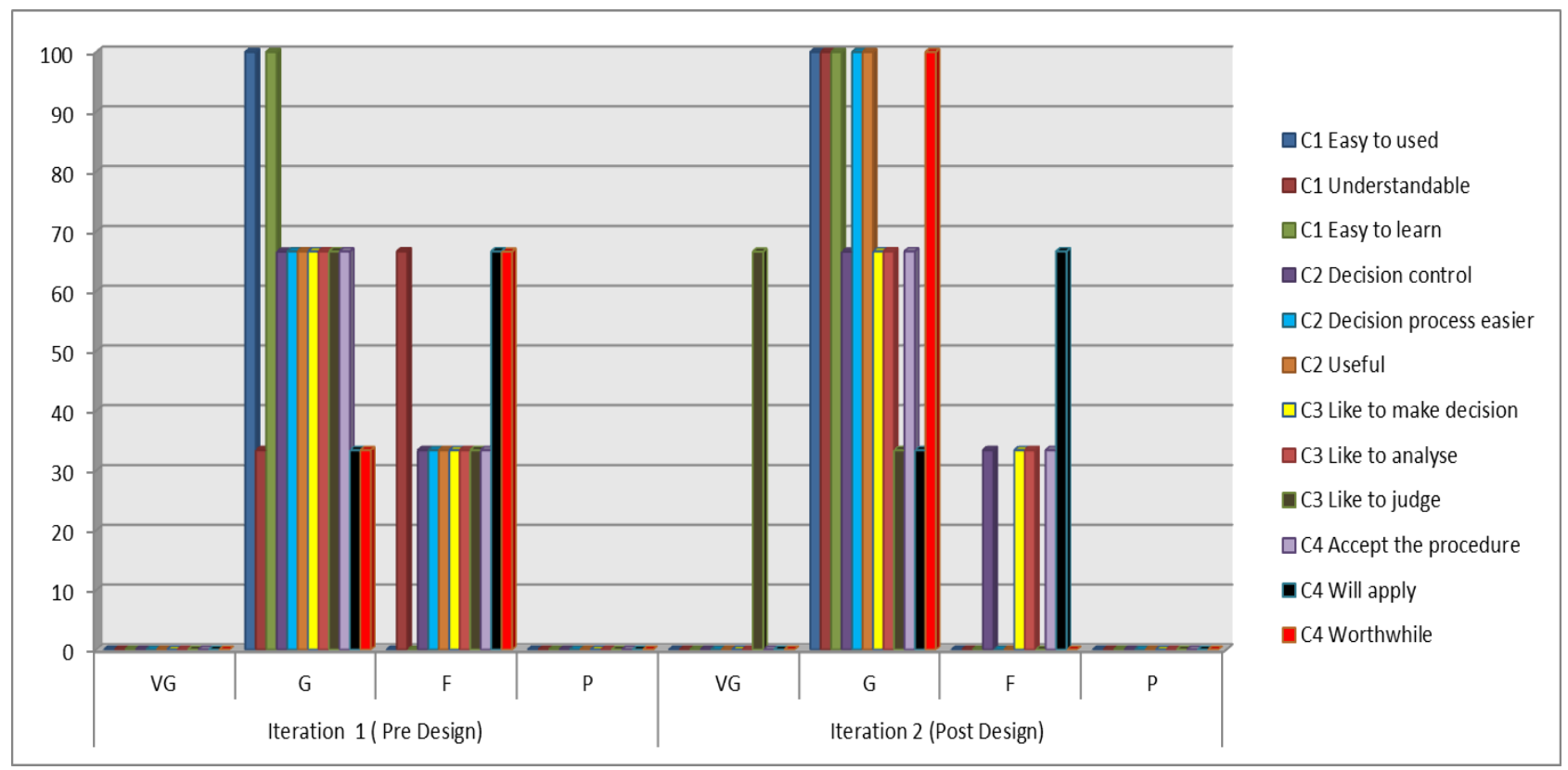

Figure 2 Result of face validation

\subsection{Qualitative Result}

For further enhance on validation of tospsi4BIM, two extra criteria was added into questionnaire which focused on design approached in topsis4BIM. The questionnaire considers the following attributes to measure the validation of this DSS;

- $\quad$ System Quality

- Information Presentation

Evaluators were asked to give their feedback and responds toward these two attributes. The result from evaluator has been analyzed through qualitative method such as content analysis.

\subsubsection{System Quality}

The objective of topsis4BIM is to assist DMs in BIM software selection decision making process. The topsis4BIM offered web decision approach that simple, accessible and capable of dealing with uncertainty environment. Thus, each of the DMs agreed on the topsis4BIM is easy to use and convenient to access, methodology behind which is Fuzzy TOPSIS is has a potential as a decision making tool for BIM software selection. However, beside DM 1, DM 2 and DM 3 have expressed their concern in the effectiveness of Fuzzy TOPSIS, even though their believed that fuzzy TOPSIS is capable of structuring the problem, but their required more time to have the confident in it. This due to the risk involved in BIM software selection such as high investment. DM3 also add if the evaluator has already experience all the alternative, and evaluate them wisely then the effectiveness of result will be increase.

\subsubsection{Information Presentation}

Information presentation is significant in order to measure the effectiveness of adoption Web 2.0 tools toward Web DSS. In conclusion, DM 1 and DM 3 were given a positive answer regarding of design of web based interface, display format and graphics in this topsis4BIM. However, DM 3 also came out with the suggestion to add login form as web based features. On the other hand, DM 2 seem not satisfied with the ways of decision model was presented. He argued the decision model presented in this topsis4BIM can be improved in future.

\subsection{CONCLUSION}

Due the rapid development of web technology has opened a new opportunity in development of web technology become more simple, mobile and effective. In this paper, a new architecture and validation of a web based DSS namely topsis4BIM integration with contemporary web technology web 2.0 is presented. It has been illustrated through a real case construction project in Malaysia. Result from validation process indicates;

- Based on the face validation result, the methodology and design approach in topsis4BIM to emulate a systematic evaluation of BIM software was satisfied.

- The ability of the model to provide alternative and innovative solution was also demonstrated.

Result from the evaluation process in this study provide sufficient evident to validate the usability and utility of the topis4BIM. Furthermore, in semi structured interview in face validation indicates that 
decision maker's acknowledge that the existence of topsis4BIM could enhance BIM software selection decision making process.

\section{Acknowledgement}

The authors gratefully acknowledge the support by the Ministry of Education Malaysia for providing the funding under Research Acculturation Grant Scheme (RAGS). We also thank the contribution by other members in Construction Innovation Research Cluster in UUM.

\section{References}

[1] R. Rohena. 2011. Building Information Modelling (BIM) Implementation in Naval Construction. Lousiana State University.

[2] Jeffrey. A. Pinheiro. 2013. List of BIM Software. [Online]. Available: http://therevitkid.blogspot.com/2013/06/list-ofbim-software.html.

[3] J. V. Kumar and M. Mukherjee. 2009. Scope of Building Information Modeling (BIM) in India. J. Eng. Sci. Technol. Rev. 2(1): 165-169.

[4] M. F. Hergunsel. 2011. Benefit of Building Information Modeling for Construction Manager And BIM Base Scheduling. Worchester Polytechnic Institute.

[5] C. Eastman, P. Teicholz, R. Sacks, and K. Liston. 2011. BIM Handbook: A Guide to Building Information Modeling for Owners, Managers, Designers, Enggineers and Contractors. Hoboken, NJ, USA: John Wiley \& Sons, Inc.

[6] D. Bryde, M. Broquetas, and J. M. Volm. 2013. The Project Benefits of Building Information Modelling (BIM). Int. J. Proj. Manag. 31 (7): 971-980.

[7] W. W. S. Lu and H. Li. 2011. Building Information Modeling and Changing Construction Practices. Autom. Constr. 20(2): 99-100.

[8] R. Sebastian. 2011. Changing roles of the clients, architects and contractors through BIM. Eng. Constr. Archit. Manag., vol. 18, no. 2, pp. 176-187.

[9] S. Azhar, M. Hein, and B. Sketo. 2007. Building Information Modeling (BIM): Benefits, Risks and Challenges.
[10] J. M. Ruiz. 2009. BIM Software Evaluation Model for General Contractors. University of Florida.

[11] G. Banias, C. Achillas, C. Vlachokostas, N. Moussiopoulos, and I. Papaioannou. 2011. A Web-based Decision Support System for the Optimal Management of Construction and Demolition Waste. Waste Manag. 31 (12): 2497-502.

[12] K. W. Chau, Y. Cao, M. Anson, and J. Zhang. 2002. Application of Data Warehouse and Decision Support System in Construction Management. Autom. Constr. 12: 213-224.

[13] M. C. Ruiz and I. Fernández. 2009. Environmental assessment in construction using a Spatial Decision Support System. Autom. Constr. 18(8): 1135-1143.

[14] L. C. M. Tang, A. Y. T. Leung, and C. W. Y. Wong. 2010. Entropic Risk Analysis by a High Level Decision Support System for Construction SMEs. J. Comput. Civ. Eng. 24: 8194.

[15] K. E. E. Kahkonen. 1995. Interactive Decision Support System for Building Construction Scheduling. J. Comput. Civ. Eng. 8(4): 519-535.

[16] K. Curran, M. Murray, and M. Christian. 2007. Taking the information to the public through Library 2.0. Libr. Hi Tech. 25(2): 288-297.

[17] D. Borenstein. 1998. Towards a Practical Method to Validate Decision Support Systems. Decis. Support Syst. 23(3): 227-239.

[18] S.-Y. Hung, Y.-C. Ku, T.-P. Liang, and C.-J. Lee. 2007. Regret Avoidance as a Measure of DSS Success: An Exploratory Study. Decis. Support Syst. 42(4): 2093-2106.

[19] H. LU, H. YU, and S. S. K. Lu. 2001. The Effects of Cognitive Style and Model Type on DSS Acceptance: An Empirical Study. Eur. J. Oper. Res. 131.

[20] A. Taroun. 2012. Decision Support System (DSS) for Construction Project Risk Analysis and Evaluation via Evidential Reasoning (ER). University of Manchester.

[21] T. J. O'Leary, M. Goul, K. E. Moffitt, and A. E. Radwan. 1990. Validating Expert System. IEEE Expert. 51-58.

[22] M. F. Omar. 2012. The Structured and Practical Approach in Development of Decision Support System for Consultan Selection in Public Sector Infrastructre Project. Queensland University of Technology.

[23] Nursal, A. T., Omar, M. F., and Nawi, M. N. M. 2014. Case Study Methodology of DSS Development for BIM Software Selection in Construction Industry. American-Eurasian Journal of Sustainable Agriculture. 8(3): 81-85.

[24] Omar, M. F. Nursal, A. T. Nawi, M. N. M. Haron, A. T. \& Goh, K. C. 2014. A Preliminary Requirement of Decision Support System for Building Information Modelling Software Selection. Malaysia Construction Research Journal (MCRJ). 15 (2): 11-19. 